\title{
Effect of Daytime Activities (Physical and Social) on Nocturnal Sleep among Residents in Elderly Homes in Lattakia, Syria
}

\author{
Fatima Adnan Hallaj, Lecturer \\ Gerontological Nursing, Faculty of Nursing, Tishreen University-Syria
}

\begin{abstract}
Despite of the high prevalence of sleep disturbances in nursing homes, yet there is a lack of research concerning the use of non-pharmacological approaches for improving residents' sleep. Objective: To assess the effect of daytime activities (physical and social) on nocturnal sleep among residents in elderly homes in Lattakia, Syria. Setting: The study was carried out in the three available homes for elderly people in Lattakia, Syria. Subjects: The study subjects comprised 40 elderly persons. They were divided randomly into two groups: study and control. Each group comprised 20 elders where elders in the control group were left to their routine while those in the study group were subjected to physical and social activities for two months. Tools: Three tools were used for data collection: the sociodemographic and clinical structure interview schedule, the environmental checklist and the Insomnia Severity Index (ISI). Results: The implemented program had a positive effect on elders' sleep status where about one fifth had no sleep problems and about a quarter showed improvement in their symptoms. Among the control group, the condition became worse for about a third. Conclusion: The program succeeded in improving sleep status of elders. This improvement was significantly affected by the duration of stay in the home, co-morbidities, drugs used and environmental factors. Recommendations: Encourage elders to perform daily exercise and to maintain social entertainment through sharing in social activities.
\end{abstract}

\section{Introduction}

Disturbances of sleep constitute a significant source of concern for elderly people. However, it is usually ignored and underdiagnosed by health care workers. It is a highly common phenomenon among elders especially those living in residential homes ${ }^{(1-}$ 3). Studies revealed that at least more than $40 \%$ of elderly home residents experience sleep disorders. A study carried out in England 2000 revealed that $40 \%$ of elders may experience insomnia, frequent awakening, and disrupted sleep ${ }^{(4)}$. In St. Louis 2004, a study reported that $70 \%$ of elderly home residents experience sleep disturbances $^{(5)}$. A study done in USA 2007 found that nearly half of elders report difficulty initiating and maintaining sleep ${ }^{(6)}$. A study done in Indian 2010 found that nearly half of older adults reported difficulty initiating and maintaining sleep ${ }^{(7)}$. In China 2013 a study reported that the prevalence of sleep disorder among elderly is $40 \%{ }^{(8)}$. A study done on Swedish population in 2014 showed that $25 \%$ of elders suffer from persistent insomnia ${ }^{(9)}$. Studies about Syrian elderly population and their health problems are still scarce.

Although, changes in Sleep physiology may be a part of the normal aging process; yet, many of these disturbances may be related to pathological processes that are not considered a normal part of aging ${ }^{(2,9)}$ Several diverse factors may contribute to sleep disturbances including health problems such as urinary incontinence, arthritis, dysnea, cardiovascular diseases, the side effects of medicines taken, retirement, relocation, death of spouse/family members, changes in circadian rhythm, age-related changes in sleep physiology, and a sedentary lifestyle. Moreover, environmental factors such as presence of noise, light, lack of privacy, uncomfortable bed also play an important role in sleep disturbances ${ }^{(1,10)}$. 
Sleep is regulated by the circadian rhythm system which synchronizes the internal sleep-wake rhythm with local day and night times based on the perception of external stimuli. This system functions as a "biological clock", causing tiredness at approximately the same time in the evening. In addition to the circadian system, the homeostatic sleep drive is the second important sleep regulation mechanism. ${ }^{(11,12)}$.

Good sleep is an important index of the quality of life. It plays an important role in physical and mental well being as it helps to conserve energy, prevent fatigue, provide organ comfort, relieve tension, and helps in protein synthesis that accelerates tissue repair. As well, during the deeper stages of sleep cognitive and emotional information is being stored, filtered, and organized ${ }^{(13,14)}$.

The inability to sleep can lead to difficulty in maintaining the attention, a slowed response time, impairments in memory and concentration, loss of productivity, and decreased performance. In addition to affecting quality of life because of excessive daytime sleepiness, as well as physical, psychological, and cognitive problems. Sleep disorders have been implicated with increased accidents, hospitalization, and mortality ${ }^{(8,15)}$.

Treating sleep problems in the elderly can improve the overall health through avoidance of over-the-counter and nonprescribed medicines, behavioral treatments, relaxation techniques, sleep hygiene, day sleep restriction, light therapy,-cognitivebehavioral therapies,-valerian, tai chi, yoga, meditation, acupuncture, and acupressure. Interventions that consist primarily of pharmacologic agents are only minimally effective and produce serious side effects including cognitive disruptions and falls $^{(1,16,17)}$.

Nowadays growing evidence suggests that increased physical and social activities may sustain daytime alertness and promote nocturnal sleep, due to thermoregulation, body restoration, and reduction of depression and anxiety ${ }^{(18,19)}$. This approach has various advantages and no side effects and may sustain sleep improvement over time. Moderate physical activity is effective in improving sleep quality where the exercises release endogenous concentrations of melatonin in the body that lead to increase the amount of deep sleep ${ }^{(20)}$. It is also possible that increasing slow-wave sleep results in improving daytime attention and accordingly the performance ${ }^{(21)}$. A lack of physical mobilization and social contact in elders' life often results in the flattening of their circadian rhythm and reduces the need for sleep in the evening. Therefore, to treat elders' sleep problem, try to compensate for the lack of environmental cues by offering additional physical exercises and social activation. Sociopsychological cues, such as daily contacts with others and structured schedules of activity, are also thought to play a role as zeitgebers (synchronizing stimuli) for the circadian variation of the sleep/ wake cycle $^{(1,11,12)}$.

Studies revealed that a combination of physical and social activities can improve sleep quality. This can be achieved by offering social and physical group activities lasting 45 minutes four times a week for a period of eight weeks ${ }^{(22-24)}$.

The gerontological nurse plays an important role in motivating the elders for a more active life style through the comprehensive assessment and design more sustainable, enduring activation programs that can be easily integrated into elders' everyday life. As well, she should create ways to enable various levels of participation in an intervention ${ }^{(1)}$.

Although Sleep quality is an important marker of quality of life, no adequate attention is given in this respect in Syria. This study needs to draw additional document on physical and social activities as an effective element for sleep quality among elderly population. 


\section{Aim of the Study}

The aim of the study is to identify the effect of daytime activities (physical and social) on nocturnal sleep among residents in elderly homes in Lattakia, Syria.

\section{Materials and Method}

\section{Materials}

Design: Quasi experimental study.

Setting: The study was carried out in all the three available residential homes for elderly people in Lattakia, Syria. These were Dar Al Ber, Dar Al Raha, and Dar Al Mowasat. These three homes are affiliated to Social Associations under the supervision of Directorate of Social Security in Lattakia which is headed by the Ministry of Social Security. These homes are financed by charities and donors that contribute in the services and in payment for elders who are unable to pay. The services provided to the residents include housing, feeding, medical health services, and recreational activities. The conditions for admission to these homes are age 60 years and more and free from mental and communicable diseases.

1- Dar El Ber: Accepts only male elders. The total number of residents is 45 elders. The number of elders in each room ranges from 2-7. There is no single rooms.

2- Dar Al Raha: Accepts both male and female elders. The number of residents is 47 elders. The number of elders in each room is 1 or 2.

3- Dar Al Mowasat: Accepts only female elders. The number of residents is $\mathbf{5 2}$ elders. The number of residents per room is 1 to 4 .

Subjects: The study subjects comprised 40 elderly from both genders residing in the previous settings and fulfilling the following criteria: age 60 years and more, reporting nocturnal sleep disturbances, able to move without assistance, mentally capable of understanding and performing the activities, no acute disease state, and agree to participate in the study.
Tools: Three tools were used to collect the data:

Tool I: Socio-demographic and clinical data structured interview schedule

It was designed by the researcher after thorough review of literature and included the following data:

1- Data about the elders': Socio demographic characteristics such as age, gender, social status, level of education, duration of stay in the home.

2- Health history: presence of chronic diseases and physical and/or psychological conditions that might affect sleep quality such as pain, dysnea, fear, worry, medication used.

3- Sleep pattern such as going to bed at regular time, using bed for other activities than sleep, sleep latency, nocturnal awakening, intake of fluid.

\section{Tool II: Environmental assessment check} $\underline{\text { list }}$

It was developed by the researcher to assess environmental constraints that might affect sleep quality such as noise, room temperature, light, uncomfortable bed.

\section{Tool III: The Insomnia Severity Index} $\underline{(\text { ISI) }}$

This scale was developed by Morin $\mathrm{C}$ et al., (2011) ${ }^{(25)}$, and used to assess the nature and symptoms of sleep problems. It is composed of seven questions that investigate the severity of symptoms, the respondent's satisfaction with his or her sleep pattern, the degree to which insomnia interferes with daily functioning, how noticeable the respondent feels his or her insomnia is to others, and the overall level of distress created by the sleep problem.

The maximum score is 28 . The total score categories is evaluated according to the score obtained in the following manner: 
0-7 No clinically significant insomnia

8-14 Subthreshold insomnia

15-21 Clinical insomnia (moderate severity)

22-28 Clinical insomnia (severe)

\section{Development of the Program:}

This was developed by the researcher after thorough review of literature. Each elderly person attended an activation program for two months. It includes two physical exercise sessions and two sessions for social activities sessions per week. The time required for each session is 45 minutes.

\section{Method}

1- Official approvals from the competent authorities to carry out the study were obtained.

2- The study tools were validated by five experts in the field of the study. Arabic translation of tool II (The Insomnia Severity Index (ISI)) was done by the researcher, validated and tested for its reliability using test retest method (after 2 weeks). It was applied to 20 elders. Spearman's correlation coefficient for ISI was $r=0.96$.

3- Informed consent from elders to participate in the study was obtained after explanation of the study purpose.

4- A pilot study was conducted on five elders selected from Dar Al Mowasat to test the study tools. The necessary modifications were made based on the results of the pilot study. These elders were excluded from the study.

5- Survey to all residents (144 elders) in the three homes was done in order to identify those fulfilling the study criteria. Those who reported having sleep disturbances were 57 elders, 6 of them refused participate in the study and from the others the researcher selected 40 elders randomly by ballot, these were the study subjects.
6- Each elder included in the study was interviewed individually to assess his sleep status before the implementation of the program using tool III.

7- The selected elders were assigned to two equal groups of 20 elders each (the study and control groups). Elders in the control group were left to their routine pattern while those in the study group were divided into four subgroups. Each sub-group consisted of 37 elders.

\section{Program implementation:}

The researcher greeted the elders, introduced herself, gave a brief summary about the benefits and components of the exercise program and asked the elders to cooperate for their benefits.

Because of elders' resistance and worry about performing any physical exercise; probably due to the sedentary life they assumed for long period in the residential homes, the researcher had to explain and demonstrate the different exercises to be performed in the study period in order to encourage the elders to participate in the program. This required 13 sessions prior the actual implementation of the physical activities in order to alleviate elders' fear and motivate them to accept to participate in the study.

During each of these sessions the researcher demonstrated one type of exercise per session and presented a video showing the performance of these exercises by elderly persons. This helped to encourage them to share in the activity. Then each elder was asked to perform the demonstrated exercise under the researcher supervision for their safety, security and to foster elder's confidence. Right practice was praised and wrong practice was corrected.

Then, the program was implemented in groups for all elders in the study group for 45 minutes per session in four sessions (one session per day) on four days per week and repeated for two months. It included two 
physical exercise sessions and two sessions for social activities weekly as following:

Before the start of the program, the researcher explained the precautions to be undertaken by the elders during performing the physical exercise to ensure and maintain the elders' safety. This included to stop immediately in case he/she feels muscle cramps or a side "stitch", or dizziness or excessive shortness of breath or fatigue. Also, she emphasized the importance of starting the exercise slowly and increase gradually according to each elder tolerance. Also, the importance to begin with warm up for 5 minutes and end with cool down for 5 minutes

As well, during these sessions, the researcher asked the participants about the type of game they like to play according to their interests. This helped in making them available by the researcher during the implementation of the program.

\section{Implementation of the physical activities:}

\section{Sessions 1 and 2:}

These sessions were implemented in the morning and lasted for 40 to 45 minutes. The elders performed the following exercises:

- Start by warm up for 5 minutes this includes: static stretching of the upper and lower limbs either while the elder is standing, sitting, or lying down. Running slowly

- Balance exercise (done for 15 minutes) while walking, then while standing. This was performed by the elder $10-$ 30 times each.

- Muscle strengthening exercise was done for 15 minutes. This included wrist curls, arm stretching, shoulder lateral raises, shoulder press, hip extension, knee curls and extension and leg raises. Each one was repeated 10 times by the elder.

- Cool down for 5 minutes which included static stretching of the upper and lower limbs either while the elder is standing, sitting, or lying down, and running slowly.

\section{Implementation of the social activities:}

\section{Sessions 3 and 4:}

These sessions were performed in the afternoon for 45 minutes each. During each of these sessions the researcher offered different games such as cards, puzzles, chess, backgammon, Parcheesi and crossword and asked the participants to select one type according to his / her interest and choose a partner to play the game with. The researcher observed the elders while playing, encouraged them, and helped them when needed. At the end of the session, the researcher praised them and gave them feedback about their achievement.

During each session, communication between elders about the game and other aspect was maintained and encouraged by the researcher. The aim of this activity is to increase interaction and socialization between elders. Also, group discussion about important events, TV programs and interesting topics were discussed in groups in the presence of the researcher.

The program was implemented for two months. The researcher asked the participants to perform the different exercises: stretching, running, balance and muscle strengthening daily in the morning while the social activities were performed daily in the afternoon. The researcher shared with the elders all the required activities whether physical or social. This helped to encourage and motivate them to continue the program. Beside small presents were given to participants after each session.

\section{Evaluation of the program:}

After the implementation of the program for two months, each of the participants in the two groups was reassessed to evaluate his sleep status using tool III "The Insomnia Severity Index (ISI)". 
Data collection started from the first of November 2013 to the end of April 2014.

\section{Ethical considerations:}

Privacy and confidentiality of the collected data was assured. Each elderly was informed about his right to withdraw from the study without penalties.

\section{Statistical Analysis}

- A chi-square test was used to study the relationship between two categorical variables.

- The Fisher's exact test was used when one or more of cells had an expected frequency of five or less.

- An independent sample t-test was used to compare the means of a normally distributed variable for the two independent groups.

- The Wilcoxon-Mann-Whitney test was used when the dependent variable was not normally distributed.

- Statistical analysis was performed using Stata (version 6).

- P value less than 0.05 was considered to be statistically significant.

\section{Limitations of the study:}

- Six elders refused to join in the exercise sessions, believing that it is of no benefit and dangerous.

- Two elders withdrew from the exercise sessions and refused to complete the sessions. These were replaced by other residents to maintain the sample size.

\section{Results}

The total sample included 40 elders. Of these $10(25.0 \%)$ were from Dar El Ber; 14 (35.0\%) from Dar Al Mowasat; and 16 (40.0\%) from Dar El Raha. Female elders constituted $55.0 \%$ of the subjects and $45.0 \%$ were males. Those with preparatory education were $55.0 \%$, or with secondary education $(27.5 \%)$ or with university degree $(17.5 \%)$. The mean age of the studied subjects was $71.3 \pm 5.9$ years.

Table (1) shows the health profile of the elders in the two groups. No significant relation was found between the two groups as regards their health profile. It appears from the table that $55.0 \%$ and $60.0 \%$ of elders in the study and control groups reported having vision problems. Those with hearing impairment were $5(25.0 \%)$ in the study and $6(30.0 \%)$ in the control group. Cardiovascular diseases were reported by the same percent in both groups $60.0 \%$ for each; musculoskeletal disorders and metabolic disorders were reported by nearly the same percent in both groups $30.0 \%$ and $25.0 \%$ and $25.0 \%$ and $20.0 \%$ respectively for the study and control groups. Urinary disorders were observed more among those in the control group $30.0 \%$ compared to only $10.0 \%$ in the study group.

Antihypertensive drugs were the most common drugs consumed by the elders in both groups $(60.0 \%$ and $50.0 \%$ respectively for the study and control groups); digitalis by $30.0 \%$ and $35.0 \%$ respectively and diuretics by $30.0 \%$ and $25.0 \%$ respectively. Antiinflammatory and analgesics by $35.0 \%$ of the study and $20.0 \%$ of the control groups.

Table (2) shows the distribution of elders according to the duration of stay in the elderly home, the number of sleeping hours and causes of sleep disturbance. No significant relation was found between the study and control groups as regards duration of stay in the home and personal and environmental factors. The duration of stay in the home was less than 1 year for $30.0 \%$ of the elders; it was one to less than 5 years for $40.0 \%$. Elders admitted to the home for 5 or more years constituted $30.0 \%$. As regards the number of sleeping hours / night 25 $(62.5 \%)$ claimed to sleep less than 6 hours and $15(37.5 \%) 6-8$ hours. Among the reported causes of sleep disturbances were taking frequent naps $80.0 \%$, lack of privacy $72.5 \%$, noise $52.5 \%$ and smoking and fluid intake before bedtime $42.5 \%$ for each. 
Table (3) shows the distribution of elders according to the type of activities performed during the day and before bedtime. No significant relation was found between the study and control groups as regard their activities during the day and before bedtime. It appears from the table that $15.0 \%$ and $20.0 \%$ of the study and control groups respectively reported doing physical activities such as range of motion exercises and walking inside or outside the home.

Those who reported social entertainment were more among the control group 35.0\% compared to $25.0 \%$ for the study group. The social activities reported by elders were playing games with other such as chess and cards, taking meals in groups in the dining room, taking coffee with other residents, and attending the home activities.

Watching TV is the main social activity reported by elders in the study group $(35.0 \%)$ followed by praying $(20.0 \%)$. The other social activities as reading, listening to radio, taking a warm bath and going to bed at regular time were reported by the same percent $15.0 \%$ for each activity. While for the control group praying was the frequent activity reported $(25.0 \%)$. Watching TV, reading and taking a warm bath were reported by $15.0 \%$ respectively for each. Listening to radio and going to bed at regular time were reported by the same percent $5.0 \%$ for each.

Using the ISI scale, table (4) shows the mean score of the sleep status of the elders in the both groups before the implementation of the program and after two months. The mean score improved (decreased) from $17.85 \pm$ 6.38 to $15.3 \pm 9.55$ in the study group while it became worse (increased) from $17 \pm 5.73$ to $20.15 \pm 7.54$ among the controls. The difference between the mean change in the two groups was statistically significant $(\mathrm{P}=0.0001)$.

Table (5) applying the insomnia severity index scale on elders attending the program before and two months after the implementation of the program (i.e. after two months) the table shows that more than half $57.14 \%$ of the elders whose sleep state was subthreshold insomnia before attending the program recovered completely after the program and $33.33 \%$ of those with moderate severity insomnia showed improvement in their symptoms after the program where it became subthreshold insomnia, and those with severe insomnia did not change after two months of the program. The differences were statistically significant $\mathrm{P}=0.0001$.

Table (6) applying the insomnia severity index scale on elders in the control group before and two months after the program implementation. The table generally shows no improvement in their symptoms where 7 $(87.5 \%)$ subthreshold did not change and 1 $(12.5 \%)$ change to moderate severity. Of those who had moderate severity state on admission in the study turned to the severity state $83.33 \%$ while those who were originally categorized in the severity state of insomnia remained severe.

Table (7) shows the relation between the elders' age, gender, and duration of stay in the home among the program group and the changes in sleep status after the implementation of the program. The table shows improvement in the sleep status among elders who attended the program sessions where the mean score of sleep status decreased from $16.73 \pm 5.95$ for females before the program to $14.09 \pm 9.39$ after but with no significant difference. The same observation was noted among males. Again the age of the elders did not affect significantly their sleep status. On the other hand, the duration of stay in the home affected significantly sleep status, the shorter the duration the increased the program effect on sleep status $(\mathrm{P}=0.05)$.

Table (8) shows the relation between the elders' medical health condition, drug consumed and environmental condition among elders who attended the program and the changes in sleep status after the program. The improvement in the sleep status among elders who attended the program was significantly associated with co-morbities, number of drugs taken, and the number of uncomfortable causes in the environment 
$(\mathrm{P}=0.0001, \quad \mathrm{P}=0.0001, \quad \mathrm{P}=0.0002$ respectively).

\section{Discussion}

Sleep problems are one of the major health concerns for elders. Good sleep is an important index to good health. Getting a good night sleep is essential for feeling refreshed and alert during the day ${ }^{(2,5)}$. When sleep need is unmet either in quantity or in quality, undesirable consequences are likely to result such as poor concentration, irritability, and feeling tired ${ }^{(4,6)}$. This can have a negative effect on daytime performance and safety leading to increased risk of falls, fractures, and even mortality. Recently researches begun to pay closer attention to the importance of social and physical activities to improve both subjective and objective ratings of sleep quality in elders $^{(7-9)}$.

Despite the growing interest in sleep and exercise, the aim of the study was to identify the effect of daytime activities (physical and social) on nocturnal sleep among residents in elderly homes in Lattakia, Syria.

The study findings indicate a significant improvement in the sleep status of elders after two months of the implementation of the program (Table 4, 5 and 6). Comparing the elders' sleep status before and after the program one can note an improvement among nearly half of the study group where one fifth of them had no sleep problems while nearly a quarter showed improvement in their symptoms (Table 4 and 5). While among the control group one third of the elders became worse. (Table 4 and 6). Elders who performed the physical and social activities had no difficulty in falling asleep or staying asleep, no problems in waking up too early, satisfied about their sleeping system, and had no sleep problem that may interact with their mode of life or their daily activities. This improvement may be attributed to the effect of the physical and social activities that increase blood flow to the brain which improves neuronal function where they help in regulating the sleep-wake rhythm by strengthening the entrainment of circadian pacemaker in the suprachiasmatic nucleus. As well, it improves the homeostatic sleep drive where the homeostatic sleep pressure progressively increases during wakeful activities. This supports the findings of some studies ${ }^{(22-24)}$, while contradicts with another study carried out in USA (2001) $)^{(26)}$ where higher figures were reported among elders who got medical treatment. This observed differences may be attributed to that the sleep status of elders in USA study were worse than those in this study which makes physical exercise and social activities ineffective and probably may need longer period of activities and share other forms of treatment.

Among the study group, more than half of the elders with Subthreshold insomnia had recovered and one third of those with clinical insomnia (moderate severity) showed improvement in their symptoms and none of those with clinical insomnia (severe) showed improvement (Table 5), while in the control group no improvement was observed on the contrary they became worse (Table 6). One can notice that physical and social activities could cure or at least may prevent the condition from getting worse. This can be due to the fact that physical and social activities improve significantly the sleep quality where they maximize sleep duration and minimize sleep latency and nocturnal awakening by enhancing homeostatic sleep drive and strengthen the entrainment of the circadian rhythm. As for those with clinical insomnia (severe), they may require longer period of physical exercises and social activities to get the benefit. The same findings were reported in other studies ${ }^{(9,14,23)}$.

Furthermore, the study revealed that the shorter the duration of stay in the residential home the more improvement in the sleep status among elders performing physical and social activities (Table 7). This may be explained by the fact that living in elderly homes encourages inhabitants to have a sedentary lifestyle characterized by a lack of physical activity, little social contact, and 
extended time spent in bed. Also, during the daytime, elders often spend limited time outdoor, often they are not exposed to sun light. This supports other studies ${ }^{(1,18)}$.

In addition, a significant relation was observed between the number of existing diseases and the improvement in sleep status, where the increased number of diseases decreases the improvement in sleep status (Table 8). This can be due to the fact that the diseases are highly morbid with sleep disturbance where medical condition may cause anxiety, pain, interfere with breathing, or cause frequent bladder or bowel elimination, and nocturnal movement disorders or nocturnal myoclonus which all contribute to frequent awakening. This result is in line with other studies ${ }^{(21,27)}$.

The number of medicines taken by elders affect significantly their improvement in sleep status, where with increased number of medicines taken improvement in sleep status decreases (Table 8). This is because the medicines may cause side effects such as interaction of drugs, insomnia, agitation, daytime sleepiness, urinary retention, and diuresis which all affect sleep quality. The same findings were reported in other studies $^{(28,29)}$.

Moreover, uncomfortable

environment has a significant relation with the improvement in sleep status, where elders who reported comfortable environment showed better improvement in their sleep status (Table 8). This is probably due to that in elderly homes there are additional environmental and institutional factors that may also contribute to elders' poor sleep such as lack of privacy by sharing room with others, inadequate temperature in the room either too hot or cool, inadequate lighting at night, presence of noise at bedtime, and uncomfortable bed. These results support those of other studies ${ }^{(1,30)}$.

Conversely, age and gender have no significant relation with the improvement in the sleep status of the elders (Table 7). This can be explained by the fact that all elders from both genders share the same risk factors conductive to sleep disturbances. The same observation was reported in other studies $^{(20,31)}$.

\section{Conclusion}

It can be concluded from the study that the physical exercises and social entertainment have a positive effect on sleep status of elders leading to either cure or at least to improve the symptoms. This improvement is affected by many factors such as duration of stay in the home and the number of the existing diseases, drugs consumed, and uncomfortable environment.

\section{Recommendations}

1- Assessment of elders residing in the elderly homes is required to detect early those who have sleep problems, and to institute appropriate measures to overcome this problem.

2- Elders should be motivated and encourage to remain active during daytime and to maintain socialization with other partners. This will help to improve nocturnal sleeping pattern.

3- Elderly homes should schedule physical and social activities in their daily routine and encourage elders to share and take active role in these activities.

4- Future research efforts should aim to optimize non-pharmacological sleep-promoting interventions in elderly homes such as exercise and socialization.

5- Create a calm quite environment to promote sleep. Provide environment which promote social interaction and motivate physical activities. 
Table (1): Distribution of elders according to their health profile.

\begin{tabular}{|c|c|c|c|c|c|c|c|}
\hline \multirow{2}{*}{ Health Profile } & \multicolumn{2}{|c|}{ Study group } & \multicolumn{2}{|c|}{$\begin{array}{l}\text { Control } \\
\text { group }\end{array}$} & \multicolumn{2}{|c|}{ Total } & \multirow[b]{2}{*}{ Significant } \\
\hline & $\begin{array}{c}\text { NO. } \\
\mathrm{n}=20\end{array}$ & $\begin{array}{c}\% \\
100\end{array}$ & $\begin{array}{l}\text { NO. } \\
\mathrm{n}=20\end{array}$ & $\begin{array}{c}\% \\
100\end{array}$ & $\begin{array}{c}\text { NO. } \\
\mathrm{n}=40\end{array}$ & $\begin{array}{c}\% \\
100\end{array}$ & \\
\hline $\begin{array}{l}\text { - Vision problem: } \\
\text { - No } \\
\text { - Yes }\end{array}$ & $\begin{array}{c}9 \\
11\end{array}$ & $\begin{array}{l}45.0 \\
55.0\end{array}$ & $\begin{array}{c}8 \\
12 \\
\end{array}$ & $\begin{array}{l}40.0 \\
60.0\end{array}$ & $\begin{array}{l}17 \\
23\end{array}$ & $\begin{array}{l}42.5 \\
57.5\end{array}$ & $\mathrm{P}=0.749$ \\
\hline $\begin{array}{l}\text { - Hearing problem: } \\
\text { - No } \\
\text { - Yes }\end{array}$ & $\begin{array}{c}15 \\
5\end{array}$ & $\begin{array}{l}75.0 \\
25.0\end{array}$ & $\begin{array}{c}14 \\
6\end{array}$ & $\begin{array}{l}70.0 \\
30.0\end{array}$ & $\begin{array}{l}29 \\
11\end{array}$ & $\begin{array}{l}72.5 \\
27.5\end{array}$ & $\mathrm{P}=0.72$ \\
\hline $\begin{array}{l}\text { - Diseases: \# } \\
\text { - None } \\
\text { - } \text { Cardiovascular } \\
\\
\text { disease } \\
\text { - } \text { Musculoskeletal } \\
\text { disorders } \\
\text { - Metabolic disorders } \\
\text { - GIT disorders } \\
\text { - Urinary disorders } \\
\text { - Respiratory } \\
\\
\text { disorders }\end{array}$ & $\begin{array}{c}3 \\
12 \\
6 \\
\\
5 \\
4 \\
2 \\
2\end{array}$ & $\begin{array}{l}15.0 \\
60.0 \\
30.0 \\
25.0 \\
20.0 \\
10.0 \\
10.0\end{array}$ & $\begin{array}{c}2 \\
12 \\
5 \\
\\
4 \\
3 \\
6 \\
1\end{array}$ & $\begin{array}{c}10.0 \\
60.0 \\
25.0 \\
\\
20.0 \\
15.0 \\
30.0 \\
5.0\end{array}$ & $\begin{array}{c}5 \\
24 \\
11 \\
\\
9 \\
7 \\
8 \\
3\end{array}$ & $\begin{array}{c}12.5 \\
60.0 \\
\\
27.5 \\
\\
22.5 \\
17.5 \\
20.0 \\
7.5\end{array}$ & $\mathrm{P}=1$ \\
\hline $\begin{array}{l}\text { - Drugs: \# } \\
\text { - None } \\
\text { - Anti hypertensive } \\
\text { - Digitals } \\
\text { - Diuretics } \\
\text { - Anti-inflammatory } \\
\text { - } \text { and analgesics } \\
\text { - Aronchodilator } \\
\text { - Hypoglycemic } \\
\text { - Vitamins } \\
\text { - } \text { minerals and } \\
\text { Potassium chloride }\end{array}$ & $\begin{array}{c}1 \\
12 \\
6 \\
6 \\
7 \\
\\
2 \\
2 \\
5 \\
2 \\
4\end{array}$ & $\begin{array}{c}5.0 \\
60.0 \\
30.0 \\
30.0 \\
35.0 \\
\\
10.0 \\
10.0 \\
25.0 \\
10.0 \\
20.0\end{array}$ & $\begin{array}{c}3 \\
10 \\
7 \\
5 \\
4 \\
\\
2 \\
1 \\
4 \\
0 \\
\\
1\end{array}$ & $\begin{array}{c}15.0 \\
50.0 \\
35.0 \\
25.0 \\
20.0 \\
10.0 \\
5.0 \\
20.0 \\
0.0 \\
5.0\end{array}$ & $\begin{array}{c}4 \\
22 \\
13 \\
11 \\
11 \\
\\
4 \\
3 \\
9 \\
2 \\
5\end{array}$ & $\begin{array}{c}10.0 \\
55.0 \\
32.5 \\
27.5 \\
27.5 \\
10.0 \\
7.5 \\
22.5 \\
5.0 \\
12.5\end{array}$ & $\mathrm{P}=0.428$ \\
\hline
\end{tabular}

* Significant $\mathrm{P} \leq 0.05$

\# More than one answer was allowed 
Table (2): Distribution of elders according to the duration of stay in the home, sleeping hours and causes of sleep disturbance.

\begin{tabular}{|c|c|c|c|c|c|c|c|}
\hline \multirow[b]{2}{*}{ Items } & \multicolumn{2}{|c|}{ Study group } & \multicolumn{2}{|c|}{$\begin{array}{c}\text { Control } \\
\text { group }\end{array}$} & \multicolumn{2}{|c|}{ Total } & \multirow{2}{*}{ Significant } \\
\hline & $\begin{array}{l}\text { NO. } \\
n=20\end{array}$ & $\begin{array}{c}\% \\
100 \\
\end{array}$ & $\begin{array}{l}\text { NO. } \\
n=20\end{array}$ & $\begin{array}{c}\% \\
100 \\
\end{array}$ & $\begin{array}{l}\text { NO. } \\
n=40\end{array}$ & $\begin{array}{c}\% \\
100 \\
\end{array}$ & \\
\hline $\begin{array}{l}\text { - Duration of stay in the home: } \\
\begin{aligned} &<1 \text { year } \\
&- 1- \\
&- 5- \\
&-10+ \\
&\end{aligned}\end{array}$ & $\begin{array}{l}7 \\
5 \\
7 \\
1\end{array}$ & $\begin{array}{c}35.0 \\
25.0 \\
35.0 \\
5.0\end{array}$ & $\begin{array}{c}5 \\
11 \\
4 \\
0\end{array}$ & $\begin{array}{c}25.0 \\
55.0 \\
20.0 \\
0.0\end{array}$ & $\begin{array}{c}12 \\
16 \\
11 \\
1\end{array}$ & $\begin{array}{c}30.0 \\
40.0 \\
27.5 \\
2.5\end{array}$ & $\mathrm{P}=0.467$ \\
\hline 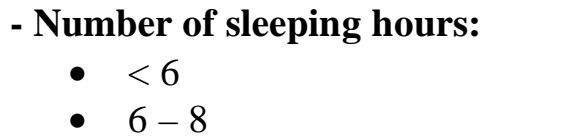 & $\begin{array}{c}11 \\
9\end{array}$ & $\begin{array}{l}55.0 \\
45.0\end{array}$ & $\begin{array}{c}14 \\
6\end{array}$ & $\begin{array}{l}70.0 \\
30.0\end{array}$ & $\begin{array}{l}25 \\
14\end{array}$ & $\begin{array}{l}62.5 \\
35.5\end{array}$ & $\mathrm{P}=0.327$ \\
\hline $\begin{array}{l}\text { - Causes of sleep disturbances: \# } \\
\text { - Personal factors: } \\
\text { - Taking naps during day } \\
\text { - Smoking before bed time } \\
\text { - Fluid intake before bed } \\
\text { time } \\
\text { - Going to toilet } \\
\text { - Fear }\end{array}$ & $\begin{array}{l}15 \\
9 \\
6 \\
4 \\
3\end{array}$ & $\begin{array}{l}75.0 \\
45.0 \\
30.0 \\
\\
20.0 \\
15.0\end{array}$ & $\begin{array}{c}17 \\
8 \\
11 \\
6 \\
2\end{array}$ & $\begin{array}{l}85.0 \\
40.0 \\
55.0 \\
30.0 \\
10.0\end{array}$ & $\begin{array}{c}32 \\
17 \\
17 \\
10 \\
5\end{array}$ & $\begin{array}{l}80.0 \\
42.5 \\
42.5 \\
\\
25.0 \\
12.5\end{array}$ & $\begin{array}{c}\mathrm{P}=0.465 \\
\mathrm{P}=0.5 \\
\mathrm{P}=0.347 \\
\mathrm{P}=0.11 \\
\mathrm{P}=0.749\end{array}$ \\
\hline 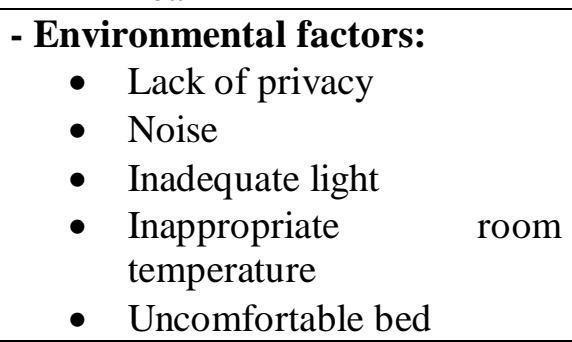 & $\begin{array}{c}15 \\
12 \\
8 \\
8 \\
7 \\
7\end{array}$ & $\begin{array}{l}75.0 \\
60.0 \\
40.0 \\
40.0 \\
35.0\end{array}$ & $\begin{array}{c}14 \\
9 \\
10 \\
7 \\
\\
8\end{array}$ & $\begin{array}{l}70.0 \\
45.0 \\
50.0 \\
35.0 \\
40.0\end{array}$ & $\begin{array}{l}29 \\
21 \\
18 \\
15 \\
\\
15\end{array}$ & $\begin{array}{l}72.5 \\
52.5 \\
45.0 \\
37.5 \\
\\
37.5\end{array}$ & $\begin{array}{l}\mathrm{P}=0.723 \\
\mathrm{P}=0.744 \\
\mathrm{P}=0.525 \\
\mathrm{P}=0.342 \\
\mathrm{P}=0.744\end{array}$ \\
\hline
\end{tabular}

* Significant $\mathrm{P} \leq 0.05$

\# More than one answer was allowed 
Table (3): Distribution of elders according to the type of activity performed during the day and before bedtime.

\begin{tabular}{|c|c|c|c|c|c|c|c|}
\hline \multirow{2}{*}{ Activities } & \multicolumn{2}{|c|}{ Study group } & \multicolumn{2}{|c|}{$\begin{array}{l}\text { Control } \\
\text { group }\end{array}$} & \multicolumn{2}{|c|}{ Total } & \multirow[b]{2}{*}{ Significant } \\
\hline & $\begin{array}{c}\text { NO. } \\
\mathrm{n}=\mathbf{2 0}\end{array}$ & $\begin{array}{c}\% \\
100\end{array}$ & $\begin{array}{c}\text { NO. } \\
\mathrm{n}=20\end{array}$ & $\begin{array}{c}\% \\
100\end{array}$ & $\begin{array}{l}\text { NO. } \\
n=40\end{array}$ & $\begin{array}{c}\% \\
100\end{array}$ & \\
\hline $\begin{array}{l}\text { - Activities performed during } \\
\text { the day: \# } \\
\text { - Physical activity } \\
\text { - Social activity }\end{array}$ & $\begin{array}{l}3 \\
5\end{array}$ & $\begin{array}{l}15.0 \\
25.0\end{array}$ & $\begin{array}{l}4 \\
7\end{array}$ & $\begin{array}{l}20.0 \\
35.0\end{array}$ & $\begin{array}{c}7 \\
12\end{array}$ & $\begin{array}{l}17.5 \\
30.0\end{array}$ & $\begin{array}{c}\mathrm{P}=0.5 \\
\mathrm{P}=0.366\end{array}$ \\
\hline $\begin{array}{l}\text { - Activities performed before } \\
\text { bedtime: \# } \\
\text { - None } \\
\text { - Watching TV } \\
\text { - Religious activity } \\
\text { - Reading } \\
\text { - Listening to radio } \\
\text { - Taking warm bath } \\
\text { - Going to bed at a } \\
\text { regular time }\end{array}$ & $\begin{array}{l}8 \\
7 \\
4 \\
3 \\
3 \\
3 \\
3\end{array}$ & $\begin{array}{l}40.0 \\
35.0 \\
20.0 \\
15.0 \\
15.0 \\
15.0 \\
15.0\end{array}$ & $\begin{array}{l}9 \\
3 \\
5 \\
3 \\
1 \\
3 \\
1\end{array}$ & $\begin{array}{c}45.0 \\
15.0 \\
25.0 \\
15.0 \\
5.0 \\
15.0 \\
5.0\end{array}$ & $\begin{array}{l}17 \\
10 \\
9 \\
6 \\
4 \\
6 \\
4\end{array}$ & $\begin{array}{l}42.5 \\
25.0 \\
22.5 \\
15.0 \\
10.0 \\
15.0 \\
10.0\end{array}$ & $\begin{array}{c}\mathrm{P}=0.749 \\
\mathrm{P}=0.144 \\
\mathrm{P}=0.5 \\
\mathrm{P}=0.669 \\
\mathrm{P}=0.302 \\
\mathrm{P}=0.669 \\
\mathrm{P}=0.302\end{array}$ \\
\hline
\end{tabular}

* Significant $\mathrm{P} \leq 0.05$

\# More than one answer was allowed

Table (4): Mean score of insomnia severity index of elders in both groups before and after two months of the implementation of the program (after two months ${ }^{\#}$ ).

\begin{tabular}{||l|c|c|c||}
\hline \hline \multirow{2}{*}{$\begin{array}{l}\text { Mean score insomnia severity index } \\
\text { (total score 28) }\end{array}$} & Study group & Control group & \multirow{2}{*}{ P value } \\
\cline { 2 - 3 } & Mean \pm SD & Mean \pm SD & \\
\hline - Before the program implementation & $17.85 \pm 6.38$ & $17 \pm 5.73$ & $\mathrm{P}=0.66$ \\
- After the program implementation & $15.3 \pm 9.55$ & $20.15 \pm 7.54$ & $\mathrm{P}=0.043^{*}$ \\
\hline Mean change \pm SD & & & \\
\hline
\end{tabular}

* Significant $\mathrm{P} \leq 0.05$

"Duration of the program $=$ two months

Before $=$ assessment before the program

After $=$ assessment immediately after the program 
Table (5): Sleep status among the study group.

\begin{tabular}{|c|c|c|c|c|c|c|c|c|c|c|c|}
\hline \multirow{3}{*}{\multicolumn{3}{|c|}{$\begin{array}{l}\text { Sleep status } \\
\text { (using ISI) }\end{array}$}} & \multicolumn{8}{|c|}{ Sleep status after\# } & \multirow{3}{*}{$P$ value } \\
\hline & & & \multicolumn{2}{|c|}{ No } & \multicolumn{2}{|c|}{$\begin{array}{l}\text { Subthreshold } \\
\text { insomnia }\end{array}$} & \multicolumn{2}{|c|}{$\begin{array}{c}\text { moderate } \\
\text { severity } \\
\text { insomnia }\end{array}$} & \multicolumn{2}{|c|}{$\begin{array}{c}\text { Severe } \\
\text { insomnia }\end{array}$} & \\
\hline & & & No. & $\%$ & No. & $\%$ & No. & $\%$ & No. & $\%$ & \\
\hline \multirow{3}{*}{$\begin{array}{l}\text { Sleep } \\
\text { status } \\
\text { before }\end{array}$} & $\begin{array}{l}\text { Subthreshold } \\
\text { insomnia }\end{array}$ & $\begin{array}{l}\text { No. } \\
n=7\end{array}$ & 4 & 57.14 & 3 & 42.86 & & & & & \multirow{3}{*}{$\begin{array}{l}\mathrm{P}=0.00 \\
01 *\end{array}$} \\
\hline & $\begin{array}{l}\text { Moderate } \\
\text { severity } \\
\text { insomnia }\end{array}$ & $\begin{array}{l}\text { No. } \\
n=6\end{array}$ & & & 2 & 33.33 & 4 & 66.67 & & & \\
\hline & $\begin{array}{l}\text { Severe } \\
\text { insomnia }\end{array}$ & $\begin{array}{l}\text { No. } \\
n=7\end{array}$ & & & & & & & 7 & 100.0 & \\
\hline
\end{tabular}

* Significant $\mathrm{P} \leq 0.05$

" Duration of the program = two months

Before $=$ assessment before the program

After $=$ assessment immediately after the program

Table (6): Sleep status among control group.

\begin{tabular}{|c|c|c|c|c|c|c|c|c|c|}
\hline \multirow{3}{*}{$\begin{array}{l}\text { Sleep status } \\
\text { (using ISI) }\end{array}$} & & & \multicolumn{6}{|c|}{ Sleep status after\# } & \multirow{3}{*}{$P$ value } \\
\hline & & & \multicolumn{2}{|c|}{$\begin{array}{l}\text { Subthreshold } \\
\text { insomnia }\end{array}$} & \multicolumn{2}{|c|}{$\begin{array}{c}\text { moderate } \\
\text { severity } \\
\text { insomnia }\end{array}$} & \multicolumn{2}{|c|}{$\begin{array}{c}\text { Severe } \\
\text { insomnia }\end{array}$} & \\
\hline & & & No. & $\%$ & No. & $\%$ & No. & $\%$ & \\
\hline \multirow{3}{*}{$\begin{array}{l}\text { Sleep status } \\
\text { before }\end{array}$} & $\begin{array}{l}\text { Subthreshold } \\
\text { insomnia }\end{array}$ & $\begin{array}{l}\text { No. } \\
n=8\end{array}$ & 7 & 87.5 & 1 & 12.5 & & & \multirow{3}{*}{$\mathrm{P}=0.0001 *$} \\
\hline & $\begin{array}{l}\text { Moderate } \\
\text { severity insomnia }\end{array}$ & $\begin{array}{l}\text { No. } \\
n=6\end{array}$ & & & 1 & 16.67 & 5 & 83.33 & \\
\hline & $\begin{array}{l}\text { Severe } \\
\text { insomnia }\end{array}$ & $\begin{array}{l}\text { No. } \\
n=6\end{array}$ & & & & & 6 & 100.0 & \\
\hline
\end{tabular}

* Significant $\mathrm{P} \leq 0.05$

\# Duration of the program = two months

Before $=$ assessment before the program

After $=$ assessment immediately after the program 
Table (7): Relation between the elders' age, gender, and duration of stay in the home among the study group and the changes in sleep status after the implementation of the program.

\begin{tabular}{|c|c|c|c|}
\hline \multirow[b]{3}{*}{$\begin{array}{l}\text { Items } \\
n=20\end{array}$} & \multicolumn{2}{|c|}{ Program implementation } & \multirow{3}{*}{ P value } \\
\hline & Before $(\mathrm{N}=20)$ & $\operatorname{After}(\mathbf{N}=20)$ & \\
\hline & Mean score \pm SD & Mean score \pm SD & \\
\hline \multicolumn{4}{|l|}{ - Age: } \\
\hline$<75$ & $14.56 \pm 6.64$ & $11.43 \pm 10.71$ & $\mathrm{P}=0.1479$ \\
\hline$\geq 75$ & $19.46 \pm 5.85$ & $17.38 \pm 8.59$ & $\mathrm{P}=0.1379$ \\
\hline \multicolumn{4}{|l|}{ - Sex: } \\
\hline Female & $16.73 \pm 5.95$ & $14.09 \pm 9.39$ & $\mathrm{P}=0.1749$ \\
\hline Male & $19.22 \pm 6.96$ & $16.78 \pm 10.12$ & $\mathrm{P}=0.1175$ \\
\hline \multicolumn{4}{|l|}{$\begin{array}{l}\text { - Duration of stay in the } \\
\text { home: }\end{array}$} \\
\hline$<5$ years & $13.57 \pm 5.65$ & $9.29 \pm 9.18$ & $\mathrm{P}=0.05^{*}$ \\
\hline$\geq 5$ years & $20.15 \pm 5.65$ & $18.54 \pm 8.36$ & $\mathrm{P}=0.41$ \\
\hline
\end{tabular}

* Significant $\mathrm{P} \leq 0.05$

Table (8): Relation between the elders' medical health condition, medication consumed and environmental condition among elders in the study group and the changes in sleep status after the program.

\begin{tabular}{||l|c|}
\hline Items & P value \\
\hline - Co-morbidities & $\mathrm{P}=0.0001^{*}$ \\
& Spearman's rho $=0.88$ \\
\hline - Drugs consumed & $\mathrm{P}=0.0001^{*}$ \\
& Spearman's rho $=0.79$ \\
\hline - Uncomfortable causes in the environment & $\mathrm{P}=0.0002^{*}$ \\
& Spearman's rho $=0.74$ \\
\hline
\end{tabular}

* Significant $\mathrm{P} \leq 0.05$ 


\section{References}

1. Roland N. Sleep disturbance among elderly people in Nursing home: A nonpharmacological approach. Human Ageing and Elderly Services 2011; 1(1): 6-26.

2. King A. King D. Physical activity for aging population. Public Health Reviews 2011; 32(2): 401-23.

3. Richards K, Lambert C, Beck C. Strength training, walking, and social activity improve sleep in nursing home and assisted living residents: randomized controlled trial. Journal of the American Geriatrics Society 2011; 59(2): 214-23.

4. Martin J, Shochat T. Assessment and treatment of sleep disturbances in older adults. Journal of Clinical Psychology 2000; 20(6): 783- 805 .

5. Cercelius C, Levenson S. The practice versus the evidence regarding sleep disturbance and solutions among residents. Journal of Caring for the Ages 2004; 5(1): 30-3.

6. Guimaraes L, Carvalho L, Yanaguibashi G, Prado G. Physically active elderly women sleep more and better than sedentary women. Sleep Medicine 2007; 9(2008): 488-93.

7. Roepke S. Sleep disorders in the elderly. Indian J Med Res 2010; 131(2): 302-310.

8. Luo J, Zhu G, Zhao Q, Guo Q, Meng H, Hong Z, Ding D. Prevalence and Risk Factors of Poor Sleep Quality among Chinese Elderly in an Urban Community: Results from the Shanghai Aging Study. PLOS 2013; 8(11): 1-7.

9. Hellström A, Hellström P, Willman A, Fagerström C. Association between Sleep Disturbances and Leisure Activities in the Elderly: A Comparison between Men and Women. Hindawi 2014; 5(1): 1-17.

10. Plamen E, Orbeta P, Janssen I, Egidio R, Keng C, Finkel S, Zee P. Daily social and physical activity increases slowwave sleep and daytime neuropsychological performance in the elderly. Sleep 2000; 23(1): 1-9.

11. Richards K, Lambert C, Beck C, Bliwise D, Evans W, Kalra G, Kleban M, Lorenz R, Rose K, Gooneratne N, Sullivan D. Strength Training and Walking Exercise and Social Activity Improve Sleep in Nursing Home and Assisted Living Residents. J Am Geriatr Soc 2011; 59(2): 214-23.

12. Reid K, Baron K, Lu B, Naylor E, Wolfe L, Zee P. Aerobic exercise improves self-reported sleep and quality of life in older adults with insomnia. Sleep Med 2010; 11(9): 934-40.

13. Zee B. Daily Social, Physical Activity Improves Sleep And Cognition In The Elderly. Northwestern University 2004; 1(12): 1-6.

14. Matheson J. Sleep disorders in the elderly. Medicine \& Health 2008; 91(5): 144-6.

15. Roccichelli J, Sanford J, Waa E. Managing sleep disorders in the elderly. The Nurse Practitioner 2010; 35(5): 307.

16. Neikrug A. Sleep disturbances in nursing homes. J Nutr Health Aging 2010; 14(3): 207-11.

17. Israel A. Sleep and its disorders in aging populations. Sleep Med 2009; 10(1): 7 11.

18. Benloucif $\mathrm{S}$, Orbeta1 L, Ortiz1 R, JanssenI, Finkel S, Bleiberg J, Zee P. Morning or Evening Activity Improves Neuropsychological Performance and Subjective Sleep Quality in Older Adults.Sleep 2004; 27(8): 1542-51. 
19. Martos V, Martín L, Pérez-Garzón V, Velarde C, Valenza-Demet G. Nursing homes: impact of sleep disturbances on functionality. Arch Gerontol Geriatr 2013; 56(3): 432-36.

20. World Health Organization. WHO Heidelberg Guidelines for Promoting Physical Activity Among Older. Available at: http://who---heidelbergguidelines-for-promoting-physicalactivity-among-older-persons.htm

21. Shirota A, Tamaki M, Hayashi M, Hori T. Effects of daytime activity on nocturnal sleep in the elderly. Psychiatry and Clinical Neurosciences 2000; 54(1): 309-10.

22. Benloucif S, Orbeta L, Ortiz R. Morning or evening activity improves neuropsychological performance and subjective sleep quality in older adults. Sleep 2004; $27(8)$ : 1542-51.

23. Richards KC, Lambert C, Beck CK, et al. Strength training, walking, and social activity improve sleep in nursing home and assisted living residents: randomized controlled trial. J Am Geriatr Soc 2011; 59(2): 214-23.

24. Kuck J, Pantke M, Flick U. Effects of social activation and physical mobilization on sleep in nursing home residents. Geriatric Nursing 2014; 35 (2014): 455-61.
25. Morin C, Belleville G, Bélanger L, Ivers $H$. The insomnia severity index: psychometric indicators to detect insomnia cases and evaluate treatment response. Sleep 2011; 34(5): 601-8.

26. Pagel J, Parnes B. Medications for the Treatment of Sleep Disorders. J Clin Psychiatry 2001; 3(3): 118-25.

27. Reid K J. Aerobic exercise improves self-reported sleep and quality of life in older adults with insomnia. Sleep Medicine2010; 11 (2010): 934-40.

28. Joshi S. Non-pharmacological therapy for insomnia in the elderly. Clinical Geriatric Medicine 2008; 24(1): 10719.

29. Bélanger L. Cognitive Behavioral Therapy for Insomnia in Older Adults, Cognitive and Behavioral Practice. Clinical Geriatric Medicine 2011; 52(3): 102-10

30. Friedman L. Scheduled Bright Light for Treatment of Insomnia in Older Adults. The American Geriatrics Society2009; 57(5): 441-52.

31. Huijuan C. Acupuncture for Treatment of Insomnia. The Journal of Alternative and Complementary Medicine 2009; 15(11): 1171-86. 